\title{
Growth Hormone Rebound After Cessation of SMS 201-995 Treatment in Acromegaly
}

\author{
L. Charest, R. Comtois, H. Beauregard and O. Serri
}

\begin{abstract}
We studied a 42-year-old woman who had persistent active acromegaly despite conventional therapies. She was treated for 6 months with SMS 201-995. Her mean plasma growth hormone GH values decreased during treatment from $9.1 \pm 1.2$ to $6.6 \pm 1.2 \mu \mathrm{g} / \mathrm{L}$. One month after the withdrawal of SMS 201-995, the plasma GH level increased to $24.4 \mu \mathrm{g} / \mathrm{L}(\mathrm{P}<0.001)$. This elevation was clinically silent and transitory, as $\mathrm{GH}$ levels decreased 8 months later to $6.9 \pm 1.3 \mu \mathrm{g} / \mathrm{L}$. Furthermore, at the beginning of therapy, her intractable headache was completely relieved; however, it progressively resumed under therapy. In conclusion, cessation of SMS 201-995 may be followed in some acromegalic patients by a rebound of plasma GH levels. This rebound suggests that SMS 201-995 decreases GH levels by an inhibition of its release from the pituitary. Furthermore, SMS 201-995 may relieve intractable headache in some acromegalic patients, but tolerance to the analgesic effect may develop.

RÉSUMÉ: Le ricochet de l'hormone à croissance aprés l'arrêt du traitement à SMS 201-995 pour l'acromégalie Nous avons évalué une malade de 42 ans qui demeurait avec une acromégalie active en dépit des traitements conventionnels. Elle fût donc traitée pendant 6 mois avec du SMS 201-995. Ses niveaux moyens d'hormone de croissance (GH) ont diminué en cours de traitement de $9.1 \pm 1.2$ à $6.6 \pm 1.2 \mu \mathrm{g} / \mathrm{L}$. Un mois après l'arrêt du SMS 201-995, les valeurs moyennes plasmatiques du GH avaient augmenté à $24.4 \mu \mathrm{g} / \mathrm{L}(\mathrm{P}<0.001)$. Cette hausse fût cliniquement silencieuse et transitoire; ainsi, les niveaux de GH diminuaient à $6.9 \pm 1.3 \mu \mathrm{g} / \mathrm{L}, 8$ mois plus tard. De plus, les céphalées rebelles de la malade sont complètement disparues au début de la thérapie. Cependant, au cours du traitement, les céphalées sont progressivement réapparues. En conclusion, l'arrêt de SMS 201-995 peut être suivi chez certains acromégales par un rebond des niveaux plasmatiques de GH. Ce rebond suggère que le SMS 201-995 diminue les niveaux de GH par une inhibition de sa relâche hypophysaire. De plus, le SMS 201-995 peut soulager les céphalées rebelles de certains acromégales; toutefois, il peut se développer une certaine tolérance à cet effet analgésique.
\end{abstract}

Can. J. Neurol.Sci. 1989; 16:442-445

The long-acting somatostatin analogue SMS 201-995 is now acknowledged to be a useful therapeutic adjunct in the longterm treatment of acromegaly when this condition cannot be cured by conventional treatment. ${ }^{1-3}$ SMS 201-995 lowers plasma growth hormone $(\mathrm{GH})$ in most acromegalic patients, 1.2 but its exact mechanism of action is still not completely understood.

We report a case of plasma GH rebound elevation after cessation of SMS 201-995 therapy in a patient with active acromegaly. These data differ from previous publications, 2,4 and we think that this observation could provide insight into the understanding of the mode of action of SMS 201-995 on GH secretion in acromegaly.

\section{Case Report}

In 1987, a 42-year-old acromegalic woman was referred to us because of persistent elevation of plasma GH. Since 1974, she had experienced the progressive appearance of amenorrhea-galactorrhea, severe headache and classical clinical features of acromegaly. In 1978, she underwent transsphenoidal surgery and was found to have a mixed GH/PRL pituitary adenoma, stage IIB, according to Hardy's classification. ${ }^{5}$ Mean levels of 8 determinations of GH and PRL obtained on 3 different days decreased postoperatively from $20 \pm 6.4$ to $10 \pm 3.1 \mu \mathrm{g} / \mathrm{L}$ and $40 \pm 8.1$ to $23 \pm 5 \mu \mathrm{g} / \mathrm{L}$ respectively. Following this operation, she was treated daily with Premarin $0.625 \mathrm{mg}$, medroxyprogesterone acetate $10 \mathrm{mg}$, levothyroxine $0.15 \mathrm{mg}$ and cortisone acetate $50 \mathrm{mg}$ for a partial hypopituitarism.

In August 1985, a dopamine agonist therapy was begun. However, the mean $\mathrm{GH}$ levels remained to $10 \mu \mathrm{g} / \mathrm{L}$ after one year of treatment with bromocriptine (up to $20 \mathrm{mg}$ daily). Consequently, in August 1986, external radiation ( $5600 \mathrm{cGy}$ given as 24 fractions of $225 \mathrm{cGy}$ each) of the pituitary fossa was performed.

In April 1987, the patient had moderate acromegalic features with normal visual fields. Fasting plasma $\mathrm{GH}$ was $10 \mu \mathrm{g} / \mathrm{L}$ and did not decrease significantly $(9.4 \mu \mathrm{g} / \mathrm{L})$ in response to $75 \mathrm{~g}$ of oral glucose. She continued to complain of intractable headache which was unresponsive to any therapy. The pain was right hemifacial in location with

From the Department of Medicine, Endocrinology Division, Notre-Dame Hospital, University of Montreal Received April 3, 1989. Accepted in final form July 29, 1989

Reprint requests to: Dr. Ronald Comtois, Endocrinology, Notre-Dame Hospital, 1560 Sherbrooke East, Montréal, Québec Canada H2L 4K8 
radiation to the right shoulder during exacerbation episodes. The pain was intense and continuous without lachrymation or rhinorrhea. It was described variously as burning or gnawing and, at times as though the skin and muscles were being stripped from the face. The patient was usually forced to lie down and shun light and noise.

In order to treat her acromegaly, a 6-month therapy with SMS 201995 was undertaken. During the study, the patient continued to take her usual hormonal replacement therapy, in addition to acetaminophen, as required. She was admitted to the Metabolic Unit for 24-hour hospitalizations. Diet was standardized. The patient gave informed consent and the study was approved by the hospital ethical committee.

\section{Methods}

For the study of the acute effects of the drug, $50 \mu \mathrm{g}$ of SMS 201-995 or placebo were administered subcutaneously (s.c.) in a single-blind manner, on 2 different days at $0900 \mathrm{~h}$ and serial blood samples for GH and PRL determination were collected throughout a 3-hour period. For the long-term effects, $100 \mu \mathrm{g}$ of SMS 201-995 was injected s.c. every $6 \mathrm{~h}$. In the last 3 months of the study, the patient received a total daily dose of $400 \mu \mathrm{g}$, delivered s.c. in 24 bolus by a portable pulsatile infusion pump (Travenol, AS6MP). Serial blood samples for plasma GH and PRL assays were drawn every hour from $0800 \mathrm{~h}$ to $20: 00 \mathrm{~h}$ through an indwelling catheter placed in the antecubital vein. These collections were made 3 days before treatment; during treatment (on the last week of therapy while the patient received on sampling day SMS 201-995, $400 \mu \mathrm{g}$, delivered s.c. in 24 bolus) and 1 and 8 months following cessation of SMS 201-995.

Plasma GH and PRL were measured by a double-antibody radioimmunoassay using reagents provided by BIO-MEGA Canada (Montreal). The samples for GH and PRL determination were measured in duplicate and then averaged. The intra- and inter-assay coefficients of variation were respectively, $6.9 \%$ and $10 \%$ for $\mathrm{GH}$, and $9 \%$ and $10.5 \%$ for PRL. The sensitivity of the assay was $0.25 \mu \mathrm{g} / \mathrm{L}$ for $\mathrm{GH}$ and approximately $2 \mu \mathrm{g} / \mathrm{L}$ for PRL. Cross reactivity between the $\mathrm{GH}$ antiserum with $\mathrm{PRL}$ and between the PRL antiserum with GH was less than $0.03 \%$ and $0.2 \%$, respectively. SMS 201-995 was kindly donated by Sandoz, Dorval, Canada.

The pituitary tumor was evaluated by high resolution computerized tomography (CT) before, at the end of therapy, and 1 and 8 months later. Contrast enhancement was used.

Data are presented as mean values \pm SD. One-way analysis of variance followed by a Mann-Whitney $U$ was performed to compare data.

\section{RESULTS}

Plasma GH levels decreased in response to a single s.c. bolus of $50 \mu \mathrm{g}$ of SMS 201-995 as compared to placebo but did not normalize (Figure 1). PRL remained stable. At the end of therapy, plasma GH had declined but had not normalized (Figure 2 and Table 1). One month after stopping SMS 201-995, the mean plasma GH had increased significantly compared to the pretreatment level $(24.4 \pm 4.2$ vs $9.1 \pm 1.2 \mu \mathrm{g} / \mathrm{L}: \mathrm{P}<0.001)$. The elevation did not persist, and 8 months after cessation of SMS 201-995, GH values had declined to a mean of $6.9 \pm 1.3 \mu \mathrm{g} / \mathrm{L}$. PRL remained stable throughout the study (Table 1). Results of plasma creatinine, glycosylated hemoglobin and glucose tolerance testing were unaltered at each evaluation and were always within the normal range. The patient noticed no clinical change, neither on therapy nor after its cessation, except for her headache. After the single s.c. bolus of SMS 201-995, her headache, which had been present for 13 years and was unresponsive to any therapy, completely resolved during a period of

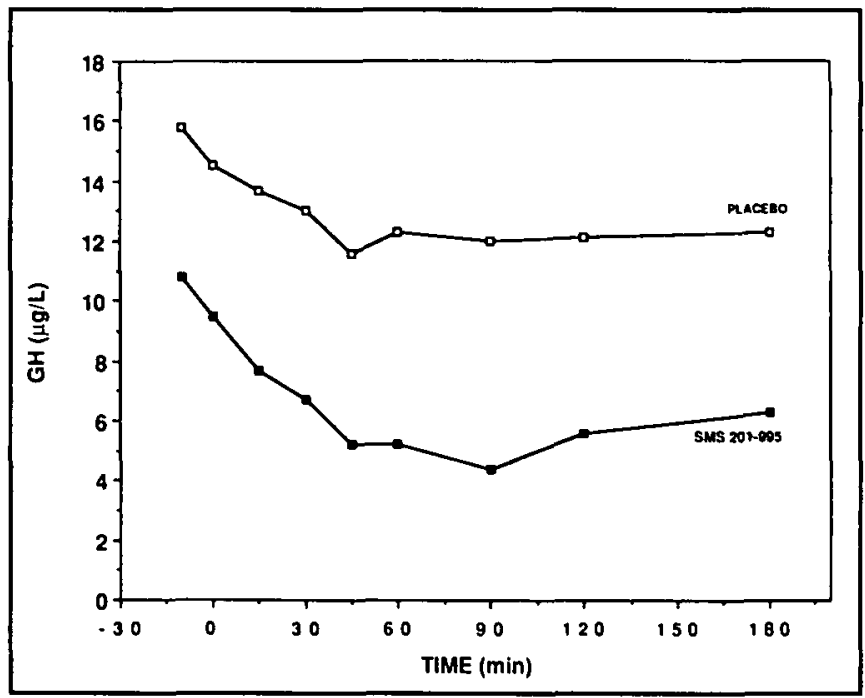

Figure 1-Comparison of $50 \mu \mathrm{g}$ s.c. of SMS 201-995 vs placebo on plasma GH concentration.

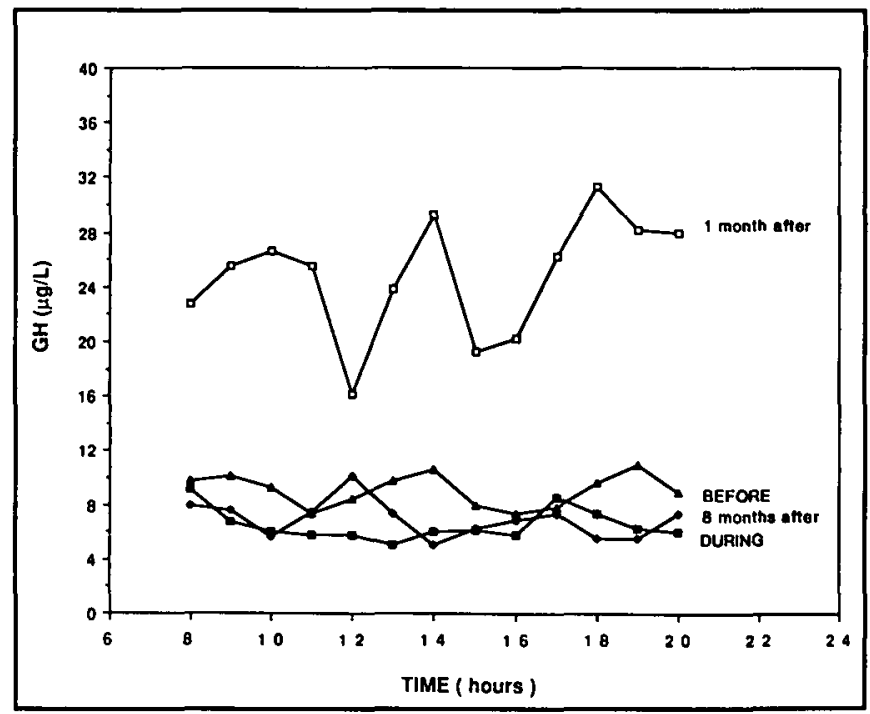

Figure 2 - Comparison of 12-hour cycles of plasma $\mathrm{GH}$ before ( $\mathbf{A}$ ) during therapy (D), $1(\square)$ and 8 months $(\diamond)$ after cessation of SMS $201-995$.

Table 1: Concentrations of Plasma GH and PRL Before, During and After SMS 201-995 During The 12-Hour Study (Mean Values \pm SD)

\begin{tabular}{lll}
\hline \hline & GH $(\mu \mathrm{g} / \mathrm{L})$ & PRL $(\mu \mathrm{g} / \mathrm{L})$ \\
\hline Before SMS 201-995 & $9.1 \pm 1.2$ & $23.7 \pm 2.1$ \\
During SMS 201-995 & $6.6 \pm 1.2^{*}$ & $23.0 \pm 2.3$ \\
1 month after stopping & $24.4 \pm 4.2^{* *}$ & $15.6 \pm 1.0$ \\
8 months after stopping & $6.9 \pm 1.3$ & $21.7 \pm 2.1$ \\
\hline
\end{tabular}

*The mean concentration of $\mathrm{GH}$ was significantly lower than its level before the therapy, $\mathrm{P}<0.05$.

${ }^{* *}$ The mean concentration of $\mathrm{GH}$ was significantly higher than its level before the therapy, $\mathrm{P}<0.001$. 
12 hours. In contrast, there was a partial decrease of her headache for 2 hours with a placebo. During the first 6-months of therapy, the patient initially had complete relief; however, her headache progressively resumed. From the third month to the end of the therapy, she received the same total daily dose but this was delivered in 24 bolus via a subcutaneous infusion pump. Again, her headache initially improved; however, it progressively resumed under treatment.

CT scan showed a tumor of $25 \times 17 \mathrm{~mm}$ before and at the end of therapy. Tumor diameters were still identical 1 and 8 months after cessation of SMS 201-995 without density modification.

\section{Discussion}

In this study, we followed a patient who had a mixed GH/PRL pituitary adenoma. Her acromegaly was still active despite previous therapies. The patient was therefore treated with SMS 201-995. Plasma GH concentrations were lowered but not normalized with 400 $\mu \mathrm{g}$ of SMS 201-995 given daily. However, a significant elevation of plasma $\mathrm{GH}$, to values well above those found before therapy, was observed 1 month after stopping SMS 201-995. This increase in plasma GH levels was transient, and 7 months later, plasma GH values had returned to pretreatment levels. An increase of plasma GH by secretion of a more active tumoral gland would probably not explain the return of $\mathrm{GH}$ to lower values. Moreover, tumor size was unchanged on CT scan at the time of the elevation of plasma $\mathrm{GH}$. Therefore, the transient increase of plasma $\mathrm{GH}$ reflects a rebound.

Lamberts et al 2,4 did not observe rebound of $\mathrm{GH}$ following SMS 201-995 therapy; however, they only examined GH levels from 24 to 48 hours after stopping the therapy. Moreover, Lamberts et al ${ }^{6}$ noted a great variability of GH secretion by pituitary tumor cells in response to SMS 201-995. In fact, their observations ranged from no response to normalization of $\mathrm{GH}$ levels in some acromegalic patients. However, a rebound phenomenon had already been described with somatostatin-14.7-9 Rebound hypergastrinemia has been reported in the 72 hours after its cessation in a treatment of one patient with gastrinoma. 10

In 1981, Prysor Jones et al, 11 incubated pituitary adenoma cells with somatostatin-14 and observed no change in hormonal synthesis organelles. However, the secretion granules were greatly increased in number and size and there was no evidence of exocytosis. George et al, 12 incubated GH-secreting pituitary adenoma cells with SMS 201-995 and found that GH release was decreased, this reduction being reversible after cessation of SMS 201-995, as demonstrated by the cells remaining responsive to GH stimulation by GRF and GH inhibition by this somatostatin analogue. There was no evidence of cytotoxicity or vasotoxicity seen on electron microscopy. Cell nucleus and cytoplasm areas were smaller than those of control cells from patients with pituitary adenomas pharmacologically untreated before resection. They noted uptake of secretory granules by lysosomes (crinophagy), and that these granules seemed to be larger; but there was only one case in this study and the treatment before resection of the tumor lasted only 10 days. These studies support the hypothesis of a reversible $\mathrm{GH}$ accumulation in secretory granules of tumoral cells and its relatively sudden release after cessation of SMS 210-995 and could explain the rebound of GH observed in our patient. No tumor shrinkage was observed in our patient, which is in agreement with Sandler et al. ${ }^{13}$ However, the GH accumulation hypothesis is probably not inconsistent with the tumor shrinkage observed in many acromegalic patients. ${ }^{2}$ In fact, George et al, 12 found that the cell areas were decreased, in spite of increased number and perhaps size of secretory granules.

PRL was unchanged by SMS 201-995, which is in agreement with Lamberts et al ${ }^{6}$ who suggested that bromocriptine and SMS 201-995 had different mechanisms of action probably involving different receptors. They also observed that pure $\mathrm{GH}$ and mixed $\mathrm{GH} / \mathrm{PRL}$ do not influence the sensitivity of GH secretion to SMS 201-995.

Clinically, the $\mathrm{GH}$ rebound was asymptomatic. This suggests that therapy and/or the rebound period were too short or that $\mathrm{GH}$ correlates weakly with clinical indexes of severity of the disease, as already reported by Clemmons et al. ${ }^{14} \mathrm{Her}$ incapacitating headache was initially relieved by SMS 201-995, but progressively resumed. Under SMS 201-995, stable improvement of severe headache associated with pituitary tumor has been reported. ${ }^{1,13,15,16}$ The mechanism by which SMS 201-995 relieves headache is unknown. SMS 201-995 decreased the plasma GH concentrations in our acromegalic patient and it is well known that hypophysectomy produced boney pain relief in about $70 \%$ of patients afflicted with cancer. ${ }^{17}$ We could postulate that the low GH levels following hypophysectomy are responsible for the amelioration of pain. However, the pain relief following hypophysectomy is not related directly to the expected fall in the levels of known pituitary hormones. In the same manner in our patient, her headache resumed although the GH levels remained unchanged. Paradoxically, Terenius 18 reported that somatostatin may function as an endogenous antagonist to the endorphin system. However, Williams et al ${ }^{15}$ suggested that somatostatin could affect the release of unknown analgesic peptides from pituitary tumors. This is the first case report of tolerance to the analgesic effect of SMS 201-995. In contrast, transient alleviation occurred quite frequently when this treatment was used in treatment of other conditions. 19,20 Thus, Kvols et al ${ }^{20}$ reported a gradual recurrence of symptoms during SMS 201-995 therapy in 5 of 22 patients with malignant carcinoid syndrome. This tolerance could be related to acceleration of the patient's SMS 201-995 metabolism; however, the stable GH levels in our patient's during the therapy did not reflect this fact. The tolerance could also be related to modification cyclic 3': 5'-monophosphate (cyclic AMP) formation because Reisine et al $^{21}$ reported that somatostatin-14 pretreatment desensitized somatostatin receptors linked to adenylate cyclase.

Overall, this case report illustrates that no definitive conclusion should be drawn about the GH levels after SMS 201-995 because of the possibility of the occurrence of a transient GH rebound following this somatostatin analogue treatment. Furthermore, the indication of SMS 201-995 for intractable headache in acromegals should be hampered by the fact that the pain relief produced by this treatment may be transitory.

\section{ACKNOWLEDGEMENTS}

We are very grateful to Mrs. Joanne Auclair for secretarial assistance and to Mrs. Fran Lowry for editing the manuscript. 


\section{REFERENCES}

1. Ch'ng LJC, Sandler LM, Kraenzlin ME, et al. Long-term treatment of acromegaly with a long acting analogue of somatostatin. $\mathrm{Br}$ Med J 1985; 290: 284-285.

2. Lamberts SWJ, Uitterlinden P, Verschoor L, et al. Long-term treatment of acromegaly with the somatostatin analogue SMS 201995. N Engl J Med 1985; 313: 1576-1580.

3. Bloom SR, Acromegaly. Am J Med 1987; 82: 88-91.

4. Lamberts SWJ, Oosterom R, Neufeld $M$, et al. The somatostatin analogue SMS 201-995 induces long acting inhibition of growth hormone secretion without rebound hypersecretion in acromegalic patients. J Clin Endocrinol Metab 1985; 60: 1161-1165.

5. Hardy T, Transsphenoidal surgery of hypersecreting pituitary tumors. In: Kohler PO, Ross GT, eds. Diagnosis and treatment of pituitary tumors. Elsevier, New York 1973; 179-185.

6. Lamberts SWJ, Verleun T, Hofland L, et al. A comparison between the effects of SMS 201-995, bromocriptine and a combination of both drugs on hormone release by the cultured pituitary tumour cells of acromegalic patients. Clin Endocrinol 1987; 27: 11-23.

7. Besser GM, Mortimer CH, Carr D, et al. Growth hormone release inhibiting hormone in acromegaly. Br Med $\mathrm{J} 1974 ; 1: 352-355$.

8. Besser GM, Mortimer CH, Mc Neilly AS, et al. Long-term infusion of growth hormone release inhibiting hormone in acromegaly: effects on pituitary and pancreatic hormones. Br Med J 1974; 4: 622-627.

9. Pieters GFFM, Romeijm JE, Smals AGH, et al. Somatostatin sensitivity and growth hormone response to releasing hormones and bromocriptine in acromegaly. J Clin Endocrinol Metab 1982; 54: 942.

10. Buck M, Kvols LK, O Dorisio TM. Rebound hypergastrinemia after cessation of a somatostatin analogue (SMS 201-995) in malignant gastrinoma. Am J Med 1987; 82: 92-95.

11. Prysor-Jones RA, Kennedy SJ, O'Sullivan JP, et al. Effect of bromocriptine, somatostatin and oestradiol-17 on hormone secretion and ultrastructure of human pituitary tumours in vitro. Acta Endocrinol 1981; 98: 14-23.
12. George SR, Kovacs K, Asa SL, et al. Effect of SMS 201-995, a long-acting somatostatin analogue, on the secretion and morphology of a pituitary growth hormone cell adenoma. Clin Endocrinol 1987; 26: 395-405.

13. Sandler LM, Burrin JM, Williams G, et al. Effective long term treatment of acromegaly with a long-acting somatostatin analogue (SMS 201-995). Clin Endocrinol 1987; 26: 85-95.

14. Clemmons DR, Van Wyk JJ, Ridgway EC, et al. Evaluation of acromegaly by radioimmunoassay of somatomedin-C. $\mathrm{N}$ Engl J Med 1979; 301: 1138-1142.

15. Williams G, Ball J, Bloom SR, et al. Improvement in headache associated with prolactinoma during treatment with a somatostatin analogue: an "n of 1" study. N Engl J Med 1986; 315: 1166-1167.

16. Williams G, Ball JA, Lawson RA, et al. Analgesic effect of somatostatin analogue (octreotide) in headache associated with pituitary tumors. Br Med J 1987; 295: 247-248.

17. Ramirez LF, Levin AB. Pain relief after hypophysectomy. Neurosurgery 1984; 14: 499-504.

18. Terenius L. Somatostatin and ACTH are peptides with partial antagonist-like selectivity for opiate receptors. Eur J Pharmacol 1976; 38: 211-213.

19. Kvols LK, Buck M, Moertel CG, et al. Treatment of metastatic islet carcinoma with a somatostatin analogue (SMS 201-995). Ann Intern Med 1987; 107: 162-168.

20. Kvols LK, Moertel CG, O'Connell MJ, et al. Treatment of the malignant carcinoid syndrome: evaluation of a long-acting somatostatin analogue (SMS 201-995). N Engl J Med 1986; 315: 663-666.

21. Reisine TD, Takahashi JS. Somatostatin pretreatment desensitizes somatostatin receptors linked to adenylate cyclase and facilitates the stimulation of cyclic adenosine $3^{\prime}: 5^{\prime}$-monophosphate accumulation in anterior pituitary tumour cells. J Neurosci 1984; 4: 812-819. 